University of Nebraska - Lincoln

DigitalCommons@University of Nebraska - Lincoln

\title{
Dryland cropping systems influence the microbial biomass and enzyme activities in a semiarid sandy soil
}

\author{
Veronica Acosta-Martinez \\ USDA-ARS, veronica.acosta-martinez@ars.usda.gov \\ Robert Lascano \\ USDA-ARS \\ Francisco Calderón \\ USDA-ARS \\ Jill D. Booker \\ USDA-ARS \\ Ted M. Zobeck \\ USDA-ARS, ted.zobeck@ars.usda.gov \\ See next page for additional authors
}

Follow this and additional works at: https://digitalcommons.unl.edu/usdaarsfacpub

Acosta-Martinez, Veronica; Lascano, Robert; Calderón, Francisco; Booker, Jill D.; Zobeck, Ted M.; and Upchurch, Dan R., "Dryland cropping systems influence the microbial biomass and enzyme activities in a semiarid sandy soil" (2011). Publications from USDA-ARS / UNL Faculty. 1228.

https://digitalcommons.unl.edu/usdaarsfacpub/1228

This Article is brought to you for free and open access by the U.S. Department of Agriculture: Agricultural Research Service, Lincoln, Nebraska at DigitalCommons@University of Nebraska - Lincoln. It has been accepted for inclusion in Publications from USDA-ARS / UNL Faculty by an authorized administrator of DigitalCommons@University of Nebraska - Lincoln. 
Authors

Veronica Acosta-Martinez, Robert Lascano, Francisco Calderón, Jill D. Booker, Ted M. Zobeck, and Dan R. Upchurch 


\title{
Dryland cropping systems influence the microbial biomass and enzyme activities in a semiarid sandy soil
}

\author{
Veronica Acosta-Martínez • Robert Lascano • \\ Francisco Calderón • Jill D. Booker • Ted M. Zobeck • \\ Dan R. Upchurch
}

Received: 18 March 2010/Revised: 11 February 2011 / Accepted: 19 February 2011 /Published online: 3 May 2011

(C) Springer-Verlag (outside the USA) 2011

This article is a U.S. government work, and is not subject to copyright in the United States.

\begin{abstract}
Indicators of soil quality, such as microbial biomass $\mathrm{C}$ and $\mathrm{N}(\mathrm{MBC}, \mathrm{MBN})$ and enzyme activities (EAs), involved in $\mathrm{C}, \mathrm{P}, \mathrm{N}$, and $\mathrm{S}$ cycling, as affected by dryland cropping systems under conventional (ct) and no tillage (nt) practices were evaluated for 5 years. The soil is sandy loam with an average of $16.4 \%$ clay, $67.6 \%$ sand, and $0.65 \mathrm{~g} \mathrm{~kg}^{-1} \mathrm{OM}$ at 0 $10 \mathrm{~cm}$. The crops evaluated were rotations of grain sorghum (Sorghum bicolor L.) or forage sorghum (also called haygrazer), cotton (Gossypium hirsutum), and winter rye (Secale cereale): grain sorghum-cotton $\left(\mathrm{Sr}_{\mathrm{g}}-\mathrm{Ct}\right)$, cotton-winter ryesorghum $\left(\mathrm{Ct}-\mathrm{Rye}-\mathrm{Sr}_{\mathrm{g}}\right)$, and forage sorghum-winter rye $\left(\mathrm{Sr}_{\mathrm{f}}-\right.$ Rye). The tillage treatments did not affect soil MB and EAs of $\mathrm{C}$ cycling (i.e., $\beta$-glucosidase, $\beta$-glucosaminidase, $\alpha$ galactosidase), $\mathrm{P}$ cycling (alkaline phosphatase, phosphodies-
\end{abstract}

USDA disclaimer Trade names and company names are included for the benefit of the reader and do not infer any endorsement or preferential treatment of the product by USDA-ARS. USDA is an equal opportunity provider and employer.

V. Acosta-Martínez $(\bowtie) \cdot$ R. Lascano $\cdot$ J. D. Booker

T. M. Zobeck

Cropping Systems Research Laboratory, Wind Erosion and Water

Conservation Unit, USDA-ARS,

3810 4th St.,

Lubbock, TX 79415, USA

e-mail: veronica.acosta-martinez@ars.usda.gov

F. Calderón

Central Great Plains Resources Management Research,

USDA-ARS,

40335 County Road GG,

Akron, CO 80720, USA

D. R. Upchurch

Southern Plains Area, USDA-ARS,

1001 Holleman Drive East,

College Station, TX 77840-4117, USA terase), and $\mathrm{S}$ cycling (arylsulfatase) - except for separation due to tillage for $\mathrm{Sr}_{\mathrm{f}}-\mathrm{Rye}$ and $\mathrm{Ct}-\mathrm{Rye}-\mathrm{Sr}_{\mathrm{g}}$ observed in PCA plots when all EAs were evaluated together. After 3 years, rotations with a winter cover crop history (Ct-Rye- $\mathrm{Sr}_{\mathrm{g}}$ and $\mathrm{Sr}_{\mathrm{f}}-$ Rye) enhanced soil MBN (up to 63\%) and EAs (21-37\%) compared to $\mathrm{Sr}_{\mathrm{g}}-\mathrm{Ct}$. After 5 years, $\mathrm{Sr}_{\mathrm{g}}-\mathrm{Ct}$ and $\mathrm{Ct}-\mathrm{Rye}-\mathrm{Sr}_{\mathrm{g}}$ showed similar soil MBC, MBN, EAs, total carbon (TC), and organic carbon (OC). A comparison of $\mathrm{Sr}_{\mathrm{g}}-\mathrm{Ct}$ plots with nearby continuous cotton $(\mathrm{Ct}-\mathrm{Ct})$ research plots in the same soil revealed that it took 5 years to detect higher TC (12\%), MBC (38\%), and EAs (32-36\%, depending on the enzyme) under $\mathrm{Sr}_{\mathrm{g}}-\mathrm{Ct}$. The significant improvements in MB and EAs found, as affected by dryland cropping systems with a history of winter cover crops and/or higher biomass return crops than cotton, can represent changes in soil OM, nutrient cycling, and $\mathrm{C}$ sequestration for sandy soils in the semiarid Texas High Plains region. It is significant that these soil changes occurred despite summer crop failure (2003 and 2006) and lack of winter cover crops (2006) due to lack of precipitation in certain years.

Keywords GRACEnet - Ogallala Aquifer - FAME analysis . Microbial biomass · Dryland · Cotton · Cropping systems

\section{Introduction}

Dryland cropping systems depend on water from precipitation, which is a significant limiting factor for production in semiarid regions including the Texas High Plains (THP), which receives about $470 \mathrm{~mm}$ of annual precipitation (Lascano 2000). Most soils in THP are sandy and have been under cotton-based cropping systems since the 1940 s, contributing to low organic matter (OM), $<1 \%$, due to the low biomass return with intensive tillage and 
winter fallow practices (Acosta-Martínez et al. 2004; Allen et al. 2005, 2008). Sustainable agricultural production systems in the semiarid THP require dryland cropping systems that lead to improvements in soil quality and functioning by increasing biomass return with minimum tillage practices and crop rotations with sorghum, which is a drought-tolerant crop.

Increases in both $\mathrm{OM}$ quality and quantity can have beneficial effects on soil quality because $\mathrm{OM}$ is related to aggregation, soil structure, and water infiltration and availability for crop production (Doran and Parkin 1994; Franzluebbers 2002). Changes in soil OM take too long to be detected; however, soil microbial communities and activities can provide earlier trends of changes in soil OM as affected by cropping systems. Microbial communities play a role in the decomposition of organic materials and plant residues incorporated into the soil, leading to energy flow, nutrient cycling, and OM build-up or soil C sequestration (Lynch and Bragg 1985; Kandeler et al. 1996). Microbial biomass $\mathrm{C}(\mathrm{MBC})$ and $\mathrm{N}(\mathrm{MBN})$ comprise $1 \%$ to $3 \%$ of total soil $\mathrm{C}$ and up to $5 \%$ of total $\mathrm{N}$ in soils, respectively, but MBC and MBN are the most active fractions of the total soil OM (Smith and Paul 1990; Franzluebbers et al. 1994). Previous studies showed that microbial communities recycle and transform nutrients in soil through enzyme-mediated reactions (Kandeler et al. 1996), which can be determined by simple, sensitive, and relatively rapid protocols compared to other biochemical analyses (Ndiaye et al. 2000; Nannipieri et al. 2002). Carbon-cycling enzyme activities (EAs) such as those of $\beta$ glucosidase, $\alpha$-galactosidase, and $\beta$-glucosaminidase distinguished cropping system-induced differences in residues degradation and nutrient incorporation in soil because these enzymes participate in the degradation of plant components such as cellobiose, melobiose, and chitin (Acosta-Martínez et al. 2007; Sotomayor-Ramírez et al. 2009). Also, $\beta$ glucosaminidase activity is involved in N-cycling as it is involved in chitin degradation (Parham and Deng 2000) and has been correlated to $\mathrm{N}$ mineralization in soils (Tabatabai et al. 2010). After N, P is the second most limiting soil nutrient for cotton (Gossypium hirsutum L.) production in the Southern High Plains (Bronson et al. 2001). Therefore, an evaluation of soil phosphatases, involved in the mineralization and transformation of $\mathrm{P}$ in soil, may provide information for one to evaluate cotton productivity. Similarly, an evaluation of arylsulfatase activity can provide information on the mineralization and transformation of $\mathrm{S}$ compounds in soil, which is essential for plant nutrition.

Studies in other regions indicate that cropping systems with diversified crops under conservation tillage can enhance soil microbial biomass and activity by increasing the residue input into the soil and reducing soil disturbance and erosion (Doran and Parkin 1994; Moore et al. 2000; Franzluebbers 2002). Furthermore, the type and quantity of plant residues that the cropping systems provide along with tillage practices will influence the soil properties differently (Liebig et al. 2006). An additional factor that affects soil properties is the length of establishment, i.e., period of the cropping system (AcostaMartínez et al. 2007, 2008). Previous studies in semiarid regions have emphasized the challenge of enhancing soil microbial communities in dryland cropping systems with low levels of biomass production due to low rain and extreme ambient temperatures (Ryan 1999; Liebig et al. 2006). Currently, there is little information on sensitive soil quality parameters, i.e., MBC, MBN, EAs, as affected by the cropping systems under dryland conditions in sandy soils, where climatic variations cause differences in biomass production or crop failure and thus disrupt cropping sequence. Therefore, our first objective was to measure crop biomass production over the first 5-year period under dryland research plots in a semiarid climate with different tillage practices and crop rotations of winter rye (Secale cereale), forage or grain sorghum (Sorghum bicolor), and cotton. The resulting cropping systems included grain sorghum-cotton $\left(\mathrm{Sr}_{\mathrm{g}}-\mathrm{Ct}\right)$, cotton-winter rye-grain sorghum (Ct-Rye- $\mathrm{Sr}_{\mathrm{g}}$ ), and forage sorghumwinter rye $\left(\mathrm{Sr}_{\mathrm{f}}-\mathrm{Rye}\right)$, managed under no tillage (nt) and conventional tillage (ct) practices. Our second objective was to evaluate how the different dryland cropping systems $\left(\mathrm{Sr}_{\mathrm{g}}-\mathrm{Ct}, \mathrm{Ct}-\mathrm{Rye}-\mathrm{Sr}_{\mathrm{g}}\right.$, and $\left.\mathrm{Sr}_{\mathrm{f}}-\mathrm{Rye}\right)$ and tillage practices, nt and ct, would modify the soil microbial biomass (MBC and MBN) and several enzyme activities of C, N, P, and S cycling. Also, MB and EAs under $\mathrm{Sr}_{\mathrm{g}}-\mathrm{Ct}$ were compared to the common cropping system in this region, i.e., a cotton monoculture $(\mathrm{Ct}-\mathrm{Ct})$ under ct. Our third objective was to explore the correlations among soil properties and to determine if changes in soil MB and/or EAs in our last sampling (representing year 5) would predict the cotton lint yields for the following year (representing year 6), when all the cropping systems were planted with cotton.

\section{Materials and methods}

\section{Cropping systems and tillage treatments}

This dryland research study was established at the USDAARS farm near New Deal, TX, USA $\left(33^{\circ} 42^{\prime} \mathrm{N}, 101^{\circ} 49^{\prime} \mathrm{W}\right.$ and average elevation of $960 \mathrm{~m}$ above sea level). Prior to this study, the land (4 ha) was fallow during fall of 2001, cotton was planted in summer 2002, and rye was grown from December 2002 to April 2003. The soil is classified as Olton sandy loam (fine, mixed, superactive, thermic Aridic Paleustolls) with an average of $16.4 \%$ clay, $67.6 \%$ sand, 
and $0.65 \mathrm{~g} \mathrm{~kg}^{-1} \mathrm{OM}$. In summer 2003, the field was divided into three replicates of a split-plot design, with cropping systems as the main treatment and tillage as subplots (each plot was $210 \mathrm{~m}$ in length). A description of the cropping systems and tillage subplots follows.

Three cropping systems in order of increasing cropping intensity $(\mathrm{CI})$ are described as follows:

1. $\mathrm{Sr}_{\mathrm{g}}-\mathrm{Ct}$

Rotation of cotton and sorghum without a winter cover crop. This rotation represents about $50 \%$ of CI because of the fallow periods without a winter cover crop.

2. Ct-Rye- $-\mathrm{Sr}_{\mathrm{g}}$ Rotation of cotton and sorghum every summer with a winter cover crop (rye). This rotation represents about $100 \%$ of CI because of using a summer and a winter crop during the year (when possible).

3. $\mathrm{Sr}_{\mathrm{f}}-\mathrm{Rye}$

High biomass cropping system with high residue crops during summer and winter, representing about $100 \%$ of CI. This system did not include a cotton crop as it has been previously reported that cotton produces less residue per hectare than the other major crops (Unger and Parker 1976; Lal 2004), and thus our objective was to investigate the maximum impact achievable on the soil properties.

The two tillage treatments are described as follows:

1. No tillage The summer above-ground crop residues were left undisturbed on the soil surface. Forage sorghum (haygrazer) and grain sorghum were laid down by grain drill and left on the surface, whereas cotton stalks remained standing.

2. Conventional tillage Summer crops were shredded and incorporated while mixing the soil up to $15 \mathrm{~cm}$ after harvest every fall. For treatments with a winter cover crop, plots were listed to create beds, $1 \mathrm{~m}$ apart, and rye was planted every fall at $62 \mathrm{~kg} \mathrm{ha}^{-1}$ on respective treatments. Beds were prepared (bed prep) again before planting (same day) every May for rotations under this tillage treatment.

The cropping systems and tillage practices mentioned earlier were replicated three times using a randomized block design. As a baseline, we used the common cropping system in the THP, i.e., tilled cotton monoculture $(\mathrm{Ct}-\mathrm{Ct})$ from nearby research plots on the same soil.
General crop management

Crops were generally planted in May. The forage sorghum (haygrazer) variety Pacesetter ${ }^{1}$ was planted at a rate of $16.8 \mathrm{~kg} \mathrm{ha}^{-1}$ with a drill at $0.4-\mathrm{m}$ spacing. Cotton, variety Paymaster 23-26rr, was planted at a rate of 9-11 $\mathrm{kg} \mathrm{ha}^{-1}$ and grain sorghum, variety $\mathrm{K} 35-\mathrm{Y} 5$, was planted at a rate of $3 \mathrm{~kg} \mathrm{ha}^{-1}$, both on 1-m row spacing. Pesticides and fertilizer were applied after rainfall events, which is a typical management practice for dryland crops in the THP. For weed control, Marksman ${ }^{\circledR}$ (Dicamba and Atrazine) herbicide was sprayed on forage and grain sorghum in July (2.34 L ha ${ }^{-1}$ ), and Round-up ${ }^{\circledR}$ (Glyphosate) herbicide was sprayed on cotton $\left(2.34 \mathrm{~L} \mathrm{ha}^{-1}\right)$. Cotton was generally chemically terminated and defoliated around mid-October using 1.17 L Cyclone ${ }^{\circledR}$ (Paraquat dichloride) $\mathrm{ha}^{-1}$. When rain was sufficient, the winter cover crop (rye) was planted in December and terminated during April of the next year using the herbicide Round-up ${ }^{\circledR}$ (Glyphosate) at $2.3 \mathrm{~L} \mathrm{ha}^{-1}$ in $\mathrm{Ct}-\mathrm{Rye}-\mathrm{Sr}_{\mathrm{g}}$ and $\mathrm{Sr}_{\mathrm{f}}-\mathrm{Rye}$ rotations.

\section{Climate data and crop measurements}

Climate data (precipitation and air temperatures) were obtained from the weather station located near these research plots. Crop biomass (cotton and forage and grain sorghum) was determined three times during the year based primarily on the growth stages of cotton since this crop has more definitive growth stages than forage or grain sorghum: first square in mid-June, first bloom the first week of July (when at least $50 \%$ of the plants have flowers), and peak bloom in August. The results from August samplings will be reported in this paper. The crop biomass samples were randomly taken from a $1-\mathrm{m}^{2}$ area from the three field replicates of a treatment plot at three locations (north, center, and south part) in each plot $(n=9)$. Biomass samples were taken from the winter cover crop following the same protocol of the summer crops.

Soil sampling and measurements

Soil samples at $0-10 \mathrm{~cm}$ in depth were collected using a hand auger. For each plot, composite samples were taken from the south and north end of the field, for a total of six samples per cropping system and tillage treatment combination (two soil samples per plot $\times$ three field replicates). The samples were taken in November 2003, 2005, and 2007, representing the start and 3 and 5 years of the study, respectively. Additionally, soil samples were taken in July

\footnotetext{
${ }^{1}$ Mention of this or other proprietary products is for the convenience of the readers only and does not constitute endorsement or preferential treatment of these products by USDA-ARS.
} 
2005 and these were used to evaluate the changes in MB and EAs during and after the 2005 growing season. Soil samples, used for baseline, were taken from a Ct-Ct under ct from a nearby field $(n=3)$. For soil MB analyses, the soil samples were sieved $(<5 \mathrm{~mm})$ and stored at $4{ }^{\circ} \mathrm{C}$ until analyses were performed within the next 2 weeks. Soil gravimetric water content was determined after drying the samples at $105^{\circ} \mathrm{C}$ for $48 \mathrm{~h}$.

The MBC and MBN contents were determined on fieldmoist soil (15 g oven-dry equivalent) samples by the chloroform fumigation-extraction method using $0.5 \mathrm{M}$ $\mathrm{K}_{2} \mathrm{SO}_{4}$ as an extractant (Brookes et al. 1985; Vance et al. 1987). Briefly, organic $\mathrm{C}$ and $\mathrm{N}$ extracted from the fumigated (24 h) and non-fumigated (control) soil were quantified by a

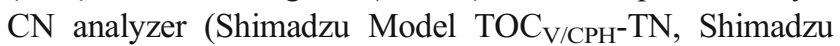
Corp., Kyoto, Japan). The MBC and MBN, difference between fumigated and non-fumigated values, were calculated using a kEC factor of 0.45 (Wu et al. 1990) and kEN factor of 0.54 (Jenkinson 1988), respectively.

The EAs, $\beta$-glucosidase, $\alpha$-galactosidase, $\beta$ glucosaminidase, alkaline phosphomonoesterase, phosphodiesterase, and arylsulfatase, were assayed using $1 \mathrm{~g}$ of airdried soil with their appropriate substrate and incubated for $1 \mathrm{~h}\left(37^{\circ} \mathrm{C}\right)$ at their optimal $\mathrm{pH}$ as described by Tabatabai (1994) and Parham and Deng (2000) for $\beta$-glucosaminidase activity. The EAs were assayed in duplicate with one control, to which substrate was added after incubation (product of all reactions is $\mathrm{PN}=\mathrm{P}$-nitrophenol).

In addition, soil $\mathrm{C}$ (organic and total) and total $\mathrm{N}, \mathrm{P}$, and " $\mathrm{NO}_{3}-\mathrm{N}$ " (available $\mathrm{N}$ ) were determined in air-dried soil samples (Ward Laboratories, Nebraska) by automated dry combustion (LECO TruSpec CN), the Mehlich P-3 method (Mehlich 1984), and $2 \mathrm{~N} \mathrm{KCl}$ extraction method (Keeney and Nelson 1982), respectively. Soil pH was measured in the air-dried soil $(<5 \mathrm{~mm})$ using a combination glass electrode (soil/water ratio, 1:2.5).

\section{Statistical analyses}

Most data were analyzed as a split-plot randomized block design with the Proc Mixed Procedure with cropping systems $\left(\mathrm{Sr}_{\mathrm{g}}-\mathrm{Ct}, \mathrm{Ct}-\mathrm{Rye}-\mathrm{Sr}_{\mathrm{g}}\right.$, and $\left.\mathrm{Sr}_{\mathrm{f}}-\mathrm{Rye}\right)$ as the main treatment and tillage (nt and ct) as subplots by using SAS software (v. 9.1.3, Cary, NC, USA). Although there were no tillage treatment effects for all the properties evaluated in this study, bar graphs were prepared with least significant differences (LSDs) for tilled and no-tillage plots individually. Also, standard errors were calculated (SigmaPlot ${ }^{\circledR}$, v. 11, Systat Software, Inc., San Jose, CA, USA) for all bar graphs as all replicates for plant $(n=9)$ and soil $(n=6)$ measurements were included. Standard errors were also calculated for the comparison of soil properties in $\mathrm{Sr}_{\mathrm{g}}-\mathrm{Ct}$ and $\mathrm{Ct}-\mathrm{Ct}$.
Three-dimensional (3D) plots were used to compare all cropping systems and tillage treatment combinations according to three related EA of $\mathrm{C}$ cycling ( $\beta$-glucosidase, $\alpha$-galactosidase, and $\beta$-glucosaminidase) or $\mathrm{P}$ and $\mathrm{S}$ cycling (alkaline phosphomonoesterase, phosphodiesterase, and arylsulfatase). A contrast comparison was performed (non-orthogonal) to investigate if there were significant differences between the EA in soil under $\mathrm{Sr}_{\mathrm{g}}-\mathrm{Ct}$ compared to $\mathrm{Ct}-\mathrm{Rye}-\mathrm{Sr}_{\mathrm{g}}$ or $\mathrm{Sr}_{\mathrm{f}}-\mathrm{Rye}$. In these 3D plots, results from $\mathrm{Ct}-\mathrm{Ct}$ under ct were included but not tested in the contrast comparison as this site is outside of the field with the cropping systems and tillage treatment combinations previously described.

Principal component analysis (PCA) was conducted in the PCORD program (Version 5) to determine differences in the soil metabolic functioning among the systems using all EAs together $(\beta$-glucosidase, $\alpha$-galactosidase, $\beta$-glucosaminidase, alkaline phosphatase, phosphodiesterase, and arylsulfatase). A monotonic transformation (square root) of all EAs was also conducted to create a more normally distributed data set and to reduce the coefficient of variation for individual EAs. The square root transformation is similar in effect to the logarithmic transformation but less drastic and is commonly used in ecological studies (McCune and Mefford 1999). The PCAs were performed using a cross-product matrix with variance-covariance centered and calculating scores for EAs by weighted averaging.

\section{Results and discussion}

Climate influence on crop establishment, management, and crop properties

The total amount and distribution of precipitation between 2003 and 2007 varied from the annual average of $470 \mathrm{~mm}$ (Fig. 1a). The minimum amount of rain was $244 \mathrm{~mm}$ in 2003 and the maximum was $692 \mathrm{~mm}$ in 2004, each representing a 100-year record-low and a record-high rainfall for this region, respectively. Thus, 2003 was a challenging year to begin this dryland study as crops failed by the end of July due to insufficient rain. Nevertheless, this year was included in our management history and is an

Fig. 1 Profile data from 2003 to 2007 of the location of the study including air temperature and precipitation (a) and crop biomass (b). For each figure in $\mathbf{b}$, the crop present during that growing season is shown in bold, and the bars with different letters within the same tillage treatment represent significant differences at $P<0.05$. Each figure in $\mathbf{b}$ also shows the cumulative heat units $(H U)$ for each crop (reported as degree Celsius per day), which are calculated as the average daily temperature minus threshold temperature ( $\operatorname{cotton}=15.5^{\circ}$ $\mathrm{C}$ and grain or forage sorghum $=10^{\circ} \mathrm{C}$ ) times the total number of days in the growing season (emergence until harvest) 
A)
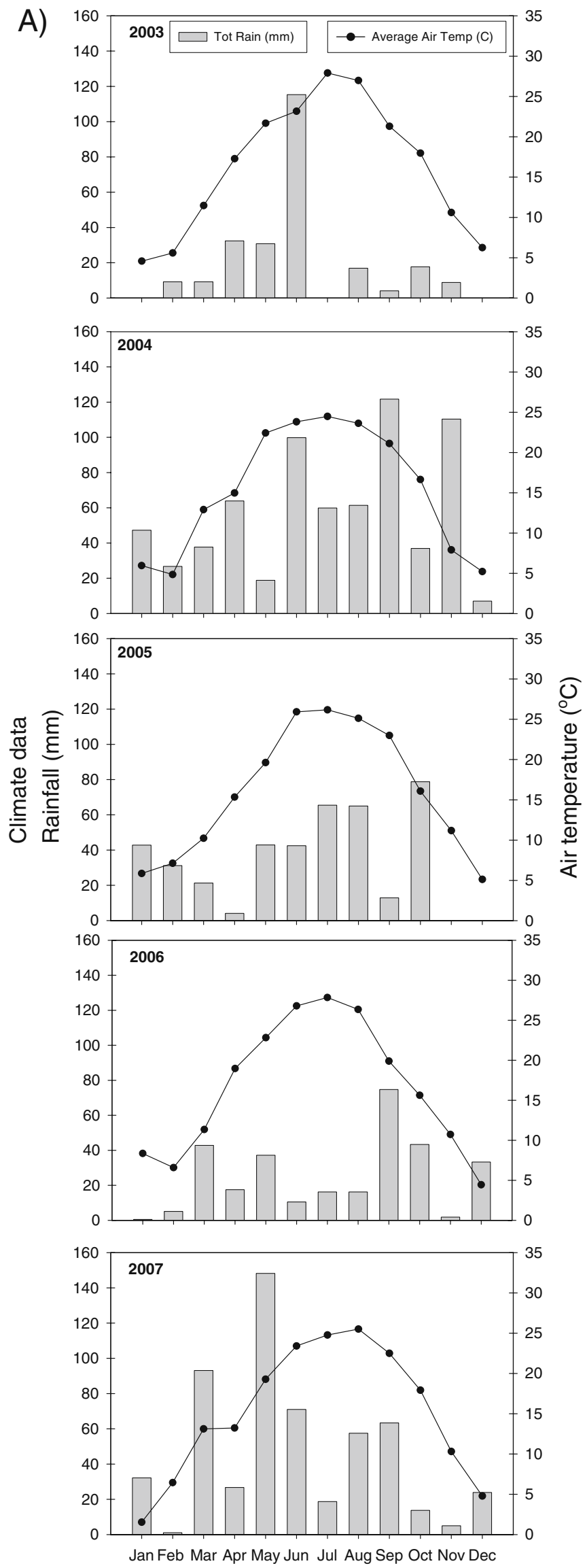

B)
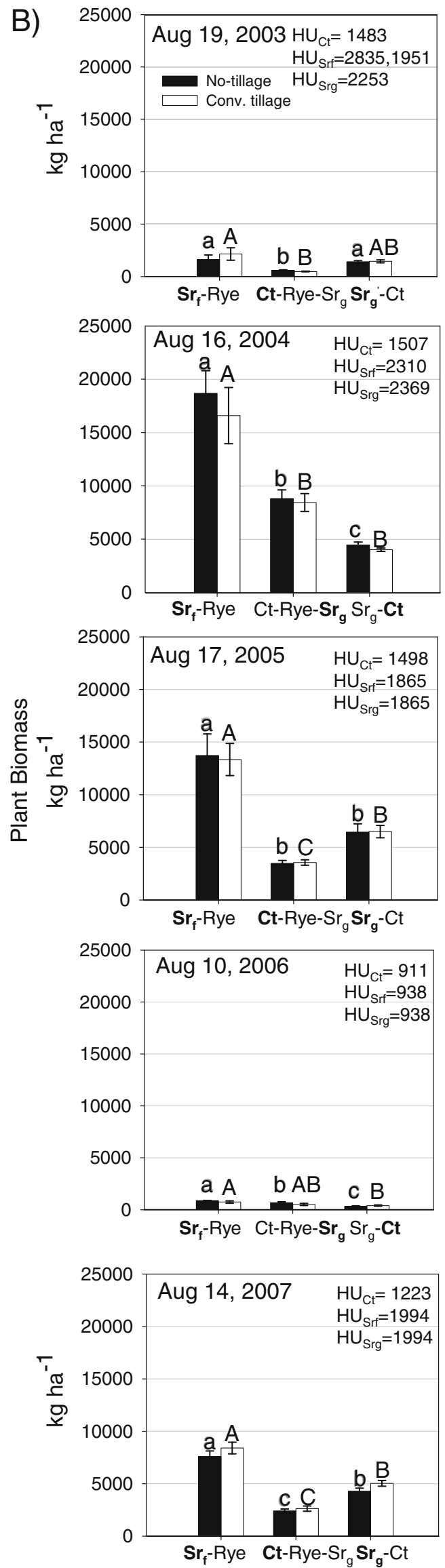
example of crop failure, which can be expected for dryland cropping systems in a semiarid region (Table 1). Plant biomass for grain and forage sorghum and for cotton crops were $<5,000 \mathrm{~kg} \mathrm{ha}^{-1}$ in August 2003 while plant biomass for August 2004 were 4,000 kg ha ${ }^{-1}$ for cotton, $8,000 \mathrm{~kg}$ $\mathrm{ha}^{-1}$ for grain sorghum, and $17,000 \mathrm{~kg} \mathrm{ha}^{-1}$ for forage sorghum (Fig. 1b). Further, given the low precipitation for 2003, the winter cover crop (rye) was not planted in the CtRye- $\mathrm{Sr}_{\mathrm{g}}$ and $\mathrm{Sr}_{\mathrm{f}}-\mathrm{Rye}$ treatments until 2004. However, winter cover crops were possible during 2004 due to the record-high precipitation.

In 2005, a total precipitation of $405 \mathrm{~mm}$ was below the long-term average, but adequate rain was received from January to October, with low precipitation in April and September (Fig. 1a). Thus, plant biomass in August 2005 (and 2004) was between 2 and 4 times higher than those in August 2003 for all crops, regardless of the cropping system and tillage practice (Fig. 1b). The 2005 winter cover crop was planted in March and terminated in May and thus provided soil surface cover for a few weeks only.
In 2006, total precipitation was $299 \mathrm{~mm}$, similar to the amount observed in 2003 (Fig. 1a). The winter rye crop had to be planted in February of this year. However, due to lack of water, it did not emerge until March and was then terminated on 1 May. As a consequence, it had a low residue on the soil surface for the Ct-Rye- $\mathrm{Sr}_{\mathrm{g}}$ and $\mathrm{Sr}_{\mathrm{f}}-\mathrm{Rye}$ plots. Because of low rainfall, i.e., $<20 \mathrm{~mm}$, between June and August, the conditions were too dry to apply fertilizers and to sustain the summer crop (Table 1). In August 2006, crop biomass was similar to those for the same month in 2003 (Fig. 1b). For this year, cotton was not harvested because the plants were shorter than average and cannot be harvested by a cotton stripper. At the end of this year, it was not possible for the winter cover crop to be planted due to extremely low rainfall.

In the 2007 growing season, cotton production was subject to lower air temperatures and higher precipitation at the beginning of summer; precipitation was close to average and warmer air temperatures occurred in the early fall. The 2007 crop biomass was up to five times higher (i.e., forage sorghum) than in 2003 and 2006 due to the wet conditions

Table 1 Cropping systems management details and summary of crop yields and cotton lint

\begin{tabular}{|c|c|c|c|c|c|c|c|c|c|c|c|}
\hline \multirow{2}{*}{$\begin{array}{l}\text { Cropping system } \\
\text { management }\end{array}$} & \multirow{2}{*}{$\frac{2003}{\text { Summer }}$} & \multirow{2}{*}{$\frac{2003 / 2004}{\text { Winter }}$} & \multirow{2}{*}{$\frac{2004}{\text { Summer }}$} & \multirow{2}{*}{$\frac{2004 / 2005}{\text { Winter }}$} & \multirow{2}{*}{$\frac{2005}{\text { Summer }}$} & \multirow{2}{*}{$-\frac{2005 / 2006}{\text { Winter }}$} & \multirow{2}{*}{$\frac{2006}{\text { Summer }}$} & \multirow{2}{*}{$\frac{2006 / 2007}{\text { Winter }}$} & \multirow{2}{*}{$\frac{2007}{\text { Summer }}$} & \multirow{2}{*}{$\frac{2007 / 2008}{\text { Winter }}$} & \multirow{2}{*}{$\frac{2008}{\text { Summe }}$} \\
\hline & & & & & & & & & & & \\
\hline $\mathrm{Sr}_{\mathrm{f}}-\mathrm{Rye}$ & $\mathrm{Sr}_{\mathrm{f}}$ & Rye & $\mathrm{Sr}_{\mathrm{f}}$ & Rye & $\mathrm{Sr}_{\mathrm{f}}$ & Rye & $\mathrm{Sr}_{\mathrm{f}}$ & Rye & $\mathrm{Sr}_{\mathrm{f}}$ & Rye & $\mathrm{Ct}$ \\
\hline Emergence & 18-Jun & 15-Dec & 21-May & $15-\mathrm{Dec}$ & 14-Jun & 15-Mar & 9-Jun & $13-\mathrm{Feb}$ & 30-May & Too dry & \\
\hline Harvest & & 26-Apr & & 28-Apr & & 1-May & & 14-May & & - & \\
\hline Yield (nt) & 1,626 & & 18,671 & & 13,720 & & 872 & 39 & 7,607 & - & 822 \\
\hline Yield (ct) & 2,146 & & 16,582 & & 13,344 & & 740 & 39 & 8,402 & - & 851 \\
\hline Ct-Rye-Sr ${ }_{g}$ & $\mathrm{Ct}$ & Rye & $\mathrm{Sr}_{\mathrm{g}}$ & Rye & $\mathrm{Ct}$ & Rye & $\mathrm{Sr}_{\mathrm{g}}$ & Rye & $\mathrm{Ct}$ & Rye & $\mathrm{Ct}$ \\
\hline Emergence & 4-Jun & 15-Dec & 19-May & 15-Dec & 23-May & 15-Mar & 1-Jun & 13-Feb & 11-Jun & Too dry & \\
\hline Harvest & 2-Oct & 26-Apr & $1-\mathrm{Nov}$ & 28-Apr & 14-Oct & 1-May & 18-Jan (2007) & 14-May & 24-Oct & - & \\
\hline Yield (nt) & & & & & 891 & & & 44 & 1,061 & - & 366 \\
\hline Yield (ct) & & & & & 949 & & & 50 & 1,100 & - & 341 \\
\hline $\mathrm{Sr}_{\mathrm{g}}-\mathrm{Ct}$ & $\mathrm{Sr}_{\mathrm{g}}$ & Fallow & $\mathrm{Ct}$ & Fallow & $\mathrm{Sr}_{\mathrm{g}}$ & Fallow & $\mathrm{Ct}$ & Fallow & $\mathrm{Sr}_{\mathrm{g}}$ & Fallow & $\mathrm{Ct}$ \\
\hline Emergence & 4-Jun & - & 17-May & - & 14-Jun & - & 9-Jun & - & 30-May & - & \\
\hline Harvest & Too dry & - & $15-$-Oct & - & 28-Nov & - & 17-Nov & - & $17-O c t$ & - & \\
\hline Yield (nt) & & - & 582 & - & & - & 139 & - & & - & 473 \\
\hline Yield (ct) & & - & 600 & - & & - & 172 & - & & - & 412 \\
\hline $\mathrm{Ct}-\mathrm{Ct}$ & & & 560 & & 773 & & 133 & & 1,062 & & 409 \\
\hline Fertilizer for all & & $0 \mathrm{~kg} \mathrm{ha}^{-1}$ & & $22.4 \mathrm{~kg} \mathrm{~N} \mathrm{ha}^{-1}$ & $28 \mathrm{~kg} \mathrm{~N} \mathrm{ha}^{-1}$ & $0 \mathrm{~kg} \mathrm{ha}^{-1}$ & & $0 \mathrm{~kg} \mathrm{ha}^{-1}$ & & & \\
\hline Application date & & - & & 25-Apr & & 1-May & & - & & - & \\
\hline
\end{tabular}

Yields $\left(\mathrm{kg} \mathrm{ha}^{-1}\right)$ are reported as August biomass measurements for grain and forage sorghum, except for cotton, which are the lint

$C t-C t$ continuous cotton, $S r_{g}-C t$ grain sorghum-cotton, $C t-R y e-S r_{g}$ cotton-winter rye-grain sorghum, $S r_{f}-R y e$ forage sorghum-winter rye, $n t$ no tillage, $c t$ conventional tillage 
during the first 6 months of the year (Fig. 1b). However, they were 1.5 times lower than in 2005 because precipitation was too high and ambient temperatures were too cold during most of the summer. The winter cover crop was not planted in 2007 due to insufficient precipitation during the winter.

Annual variations in biomass production during this 5 -year period provide evidence that low rainfall will produce low biomass and $\mathrm{C}$ inputs in dryland cropping systems for this region; a result that has been reported for another semiarid region (Liebig et al. 2006). In general, the cotton biomass from the nearby dryland $\mathrm{Ct}-\mathrm{Ct}$ plots, baseline, was similar to the cotton biomass of any rotation studied (Table 1). Thus, cotton lint yields were not influenced by crop rotation or tillage history during the 5 years of our study (2003-2007). However, cotton lint were higher under $\mathrm{Sr}_{\mathrm{f}}-$ Rye compared to the other cropping systems in 2008, when cotton was grown in all these dryland cropping systems, and there were no differences due to tillage practices (Table 1). In contrast, Feng et al. (2003) reported a $4 \%$ higher lint yield for a no-till treatment compared to a conventional-till treatment after 12 years for a silt loam soil with continuous cotton. This result suggest that increases in cotton lint yield due to cropping system and tillage management are possible but will require more than 5 years to detect the effects of crop rotations and tillage practices on cotton lint yield.

\section{Soil total C, total N, microbial biomass $\mathrm{C}$ and $\mathrm{N}$}

Minimum tillage provides an extensive rooting system and soil surface protection with crop residues, which has influenced increases in $\mathrm{MB}$ for soils of higher $\mathrm{OM}$ than the soil evaluated here, and these increases in MB have been associated with positive changes in soil quality and C sequestration (Karlen et al. 1999; Moore et al. 2000; Acosta-Martínez et al. 2004, 2010a; Sotomayor-Ramírez et al. 2009). In this study, it was not expected that soil total $\mathrm{C}$ (TC) and total N (TN) would be impacted by the tillage treatments after 5 years (Table 2), but it was surprising that MBC and MBN were not affected by the tillage treatments as they represent the living and biologically most active fraction of SOM (Fig. 2). It is possible that changes in MB may take longer for sandy soils in a semiarid climate with no tillage practices under dryland cropping systems. For example, Feng et al. (2003) reported increases in SOC $(130 \%)$, total $\mathrm{N}(70 \%)$, and $\mathrm{MBC}$ (up to $140 \%$ ) in the surface layer of a silt loam under nt continuous cotton for 12 years when compared to ct. Another study provided evidence of higher cotton root biomass production and $\mathrm{C}$ concentrations under nt than ct in surface soils (Sainju et al. 2005). More highly mineralized $\mathrm{C}$ and $\mathrm{N}$, up to $15 \mathrm{~cm}$ in depth under reduced tillage than ct, demonstrated increases in nutrient cycling with a changed rhizosphere environment and microbial communities under minimum tillage (Wright et al. 2008).

Cropping systems did not impact soil TC and TN until year 5 when soil under $\mathrm{Sr}_{\mathrm{f}}$-Rye showed higher $\mathrm{TC}$ and $\mathrm{TN}$ than the other dryland cropping systems (Table 2). However, rotations with a winter cover $\left(\mathrm{Sr}_{\mathrm{f}}-\mathrm{Rye}\right.$ and $\left.\mathrm{Ct}-\mathrm{Rye}-\mathrm{Sr}_{\mathrm{g}}\right)$ showed higher MBC (up to $50 \%$ ) and MBN (up to $63 \%$ ) compared to a rotation without winter cover crop $\left(\mathrm{Sr}_{\mathrm{g}}-\mathrm{Ct}\right)$ after only 3 years as shown in Fig. 2 (July 2005) and Fig. 3

Table 2 Selected soil properties under different the dryland cropping systems evaluated

\begin{tabular}{|c|c|c|c|c|c|c|c|c|c|c|c|c|c|c|}
\hline \multirow{2}{*}{$\begin{array}{l}\text { Cropping } \\
\text { System }\end{array}$} & \multicolumn{2}{|c|}{ Organic $\mathrm{C}$} & \multicolumn{2}{|l|}{ Total C } & \multicolumn{2}{|c|}{ Total N } & \multicolumn{2}{|l|}{$\mathrm{NO}_{3}-\mathrm{N}$} & \multicolumn{2}{|l|}{$\mathrm{P}$} & \multicolumn{2}{|c|}{ Soil pH } & \multicolumn{2}{|c|}{ Soil moisture } \\
\hline & \multicolumn{4}{|c|}{$\mathrm{g} \mathrm{kg}^{-1}$ soil } & No-till & Till & No-till & Till & \multicolumn{2}{|c|}{$\mathrm{mg} \mathrm{kg}^{-1}$ soil } & No-till & Till & $\begin{array}{l}\text { No-till } \\
\%\end{array}$ & Till \\
\hline \multicolumn{15}{|c|}{ Nov. 2003 ( beginning of the study) } \\
\hline $\mathrm{Sr}_{\mathrm{f}}-$ Rye & n.d. & n.d. & $5.30 \mathrm{a}$ & $5.38 \mathrm{a}$ & $0.54 \mathrm{a}$ & $0.53 \mathrm{a}$ & $5.0 \mathrm{~b}$ & $4.7 b$ & $27.0 \mathrm{a}$ & $25.7 \mathrm{a}$ & $7.5 \mathrm{a}$ & $7.6 \mathrm{a}$ & $3.3 \mathrm{a}$ & $3.4 \mathrm{a}$ \\
\hline Ct-Rye- $-\mathrm{Sr}_{\mathrm{g}}$ & n.d. & n.d. & $5.17 \mathrm{a}$ & $5.17 \mathrm{a}$ & $0.50 \mathrm{a}$ & $0.50 \mathrm{a}$ & $6.8 \mathrm{a}$ & $6.6 \mathrm{a}$ & $26.3 \mathrm{a}$ & $27.2 \mathrm{a}$ & $7.4 \mathrm{a}$ & $7.5 \mathrm{a}$ & $3.3 \mathrm{a}$ & $3.0 \mathrm{~b}$ \\
\hline $\mathrm{Sr}_{\mathrm{g}}-\mathrm{Ct}$ & n.d. & n.d. & $5.42 \mathrm{a}$ & $5.07 \mathrm{a}$ & $0.54 \mathrm{a}$ & $0.48 \mathrm{a}$ & $4.6 \mathrm{~b}$ & $4.2 b$ & $23.8 \mathrm{a}$ & $21.8 b$ & $7.5 \mathrm{a}$ & $7.5 \mathrm{a}$ & $3.6 \mathrm{a}$ & $3.4 \mathrm{a}$ \\
\hline \multicolumn{15}{|c|}{ Nov. 2005 (year 3 of the study) } \\
\hline $\mathrm{Sr}_{\mathrm{f}}-$ Rye & n.d. & n.d. & $5.62 \mathrm{a}$ & $6.00 \mathrm{a}$ & $0.56 \mathrm{a}$ & $0.59 \mathrm{a}$ & $2.5 b$ & $1.8 \mathrm{~b}$ & $33.3 \mathrm{a}$ & $32.8 \mathrm{a}$ & $7.7 \mathrm{a}$ & $7.7 \mathrm{a}$ & $6.9 \mathrm{~b}$ & $5.5 \mathrm{c}$ \\
\hline Ct-Rye--Sr & n.d. & n.d. & $5.30 \mathrm{a}$ & $5.35 b$ & $0.51 \mathrm{a}$ & $0.50 \mathrm{a}$ & $7.0 \mathrm{a}$ & $6.6 \mathrm{a}$ & $25.8 \mathrm{a}$ & $24.2 b$ & $7.5 \mathrm{a}$ & $7.6 \mathrm{a}$ & $9.6 \mathrm{a}$ & $9.6 \mathrm{a}$ \\
\hline $\mathrm{Sr}_{\mathrm{g}}-\mathrm{Ct}$ & n.d. & n.d. & $5.13 \mathrm{a}$ & $4.75 b$ & $0.49 \mathrm{a}$ & $0.41 \mathrm{a}$ & $2.2 b$ & $2.7 \mathrm{~b}$ & $27.8 \mathrm{a}$ & $27.2 \mathrm{ab}$ & $7.5 \mathrm{a}$ & $7.5 \mathrm{a}$ & $7.5 b$ & $7.6 \mathrm{~b}$ \\
\hline \multicolumn{15}{|c|}{ Nov. 2007 (year 5 of the study) } \\
\hline $\mathrm{Sr}_{\mathrm{f}}-$ Rye & $5.57 \mathrm{a}$ & $5.68 \mathrm{a}$ & $5.92 \mathrm{a}$ & $5.93 \mathrm{a}$ & $0.57 \mathrm{a}$ & $0.58 \mathrm{a}$ & $0.5 b$ & $0.2 \mathrm{~b}$ & $32.7 \mathrm{a}$ & $29.5 \mathrm{a}$ & $7.1 \mathrm{a}$ & $7.1 \mathrm{a}$ & $4.6 \mathrm{a}$ & $3.9 \mathrm{a}$ \\
\hline Ct-Rye- $-\mathrm{Sr}_{\mathrm{g}}$ & $4.93 b$ & $5.05 b$ & $5.25 \mathrm{~b}$ & $5.48 \mathrm{~b}$ & $0.49 \mathrm{a}$ & $0.55 \mathrm{a}$ & $1.5 \mathrm{a}$ & $4.1 \mathrm{a}$ & $32.8 \mathrm{a}$ & $31.5 \mathrm{a}$ & $7.0 \mathrm{a}$ & $7.1 \mathrm{a}$ & $3.7 \mathrm{~b}$ & $3.5 \mathrm{~b}$ \\
\hline $\mathrm{Sr}_{\mathrm{g}}-\mathrm{Ct}$ & $4.80 \mathrm{~b}$ & $4.83 b$ & $5.32 b$ & $5.18 \mathrm{~b}$ & $0.51 \mathrm{a}$ & $0.51 \mathrm{a}$ & $0.4 \mathrm{~b}$ & $0.3 b$ & $25.3 b$ & $33.3 \mathrm{a}$ & $7.2 \mathrm{a}$ & $7.2 \mathrm{a}$ & $3.8 \mathrm{~b}$ & $3.3 b$ \\
\hline
\end{tabular}

Different letters indicate significant differences among cropping systems for each year from LSDs at $P<0.05$

$C t-C t$ continuous cotton, $S r_{g}-C t$ grain sorghum-cotton, $C t-R y e-S r_{g}$ cotton-winter rye-grain sorghum, $S r_{f}-R y e$ forage sorghum-winter rye, $n t$ no tillage, $c t$ conventional tillage 

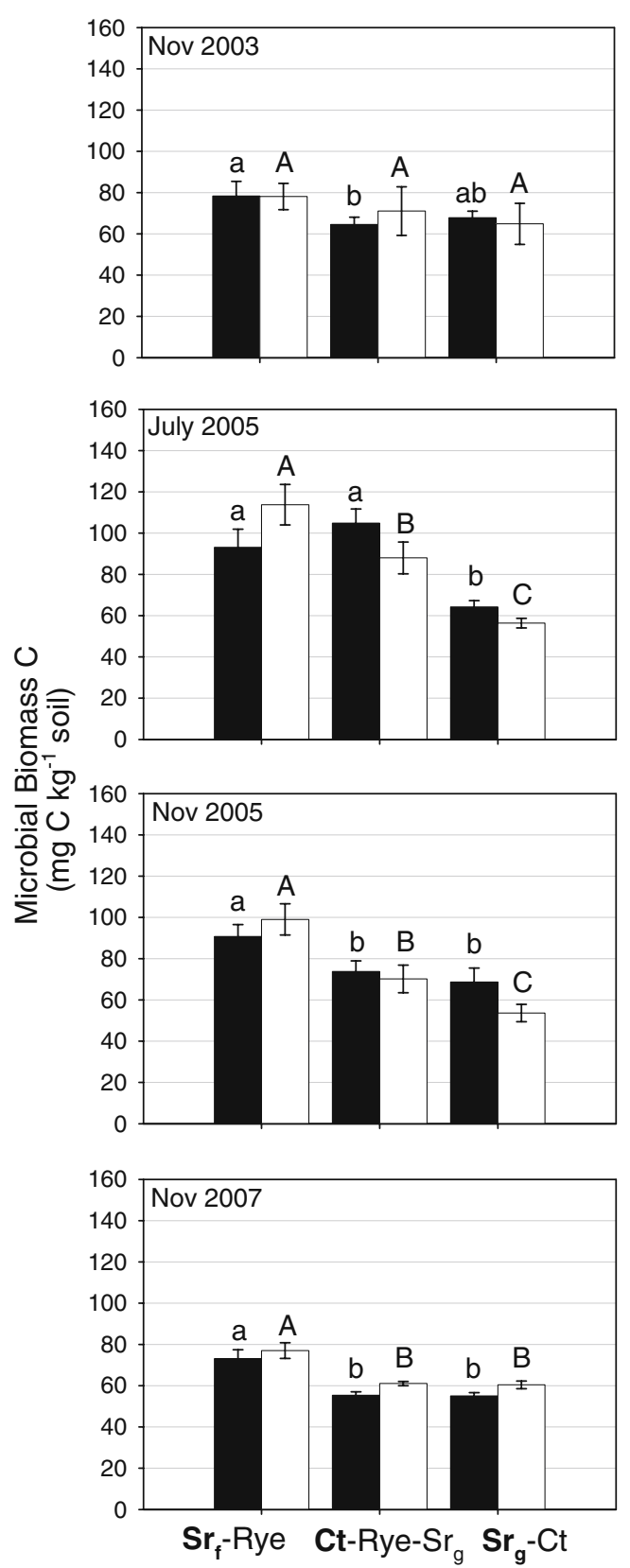

Fig. 2 Soil $M B C$ as affected by the cropping systems and tillage treatments. Samples were taken from 0 to $10 \mathrm{~cm}$ in Nov 2003 (initiation of the study), Nov and July 2005 (3 years), and Nov 2007 (5 years of the study). Bars with different letters within the same tillage treatment represent significant differences at $P<0.05$

(July and Nov samplings), respectively. These findings demonstrate early impacts, after 3 years, in microbial biomass despite variations in crop biomass produced every year for this sandy soil. By the Nov 2007 sampling, representing 5 years of this study, $\mathrm{MBC}$ and $\mathrm{MBN}$ were similar in soil under $\mathrm{Ct}-\mathrm{Rye}-\mathrm{Sr}_{\mathrm{g}}$ and $\mathrm{Sr}_{\mathrm{g}}-\mathrm{Ct}$. These results suggest that a cropping system without a winter cover crop, e.g., $\mathrm{Sr}_{\mathrm{g}}-\mathrm{Ct}$, would need a longer time to reach soil MB levels of a rotation with winter cover crops such as $\mathrm{Ct}-\mathrm{Rye}-\mathrm{Sr}_{\mathrm{g}}$ under dryland conditions and/or this soil type. Further, a comparison of $\mathrm{Sr}_{\mathrm{g}}-\mathrm{Ct}$ plots with $\mathrm{Ct}-\mathrm{Ct}$ in nearby plots showed that soil MB was higher by $38 \%$ under $\mathrm{Sr}_{\mathrm{g}}-\mathrm{Ct}$ than $\mathrm{Ct}-\mathrm{Ct}$ after 5 years of establishment of the alternative cropping system (Table 3). These findings suggest that soil microbial biomass in cotton-based cropping systems, without winter cover crops, may be more sensitive to environmental disturbances common for semiarid regions, such as periods of
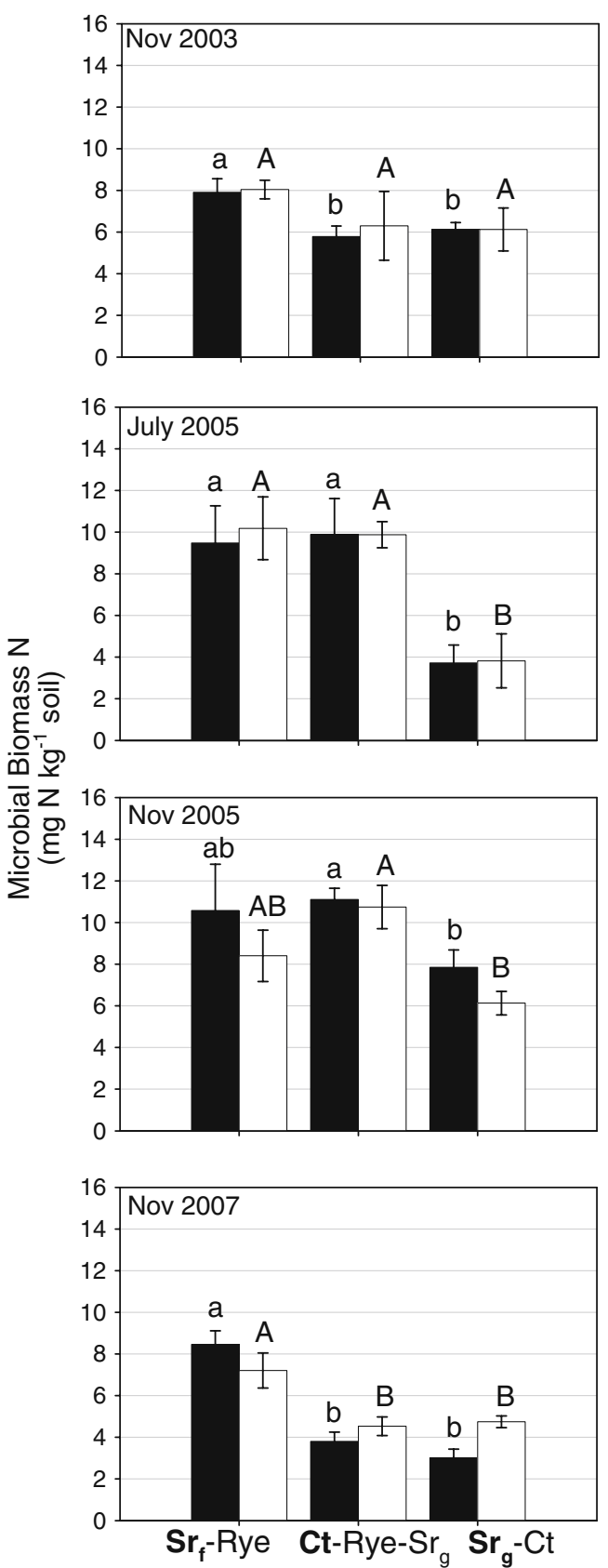

Fig. 3 Soil MBN as affected by the cropping systems and tillage treatments. Samples were taken from 0 to $10 \mathrm{~cm}$ in Nov 2003 (initiation of the study), Nov and July 2005 (3 years), and Nov 2007 ( 5 years of the study). Bars with different letters within the same tillage treatment represent significant differences at $P<0.05$ 
Table 3 Comparison of selected soil properties in grain sorghum-cotton and continuous cotton both under conventional tillage practices

\begin{tabular}{|c|c|c|c|c|}
\hline Soil property & Sampling (Nov.) & $\mathrm{Ct}-\mathrm{Ct}$ & $\mathrm{Sr}_{\mathrm{g}}-\mathrm{Ct}$ & $\begin{array}{l}\text { Difference between } \mathrm{Sr}_{\mathrm{g}}-\mathrm{Ct} \\
\text { compared to } \mathrm{Ct}-\mathrm{Ct}(\%)\end{array}$ \\
\hline \multirow[t]{2}{*}{ Total C ( $\mathrm{g} \mathrm{kg}^{-1}$ soil) } & 2005 & $4.80(0.12)$ & $4.75(0.10)$ & _ \\
\hline & 2007 & $4.23(0.06)$ & $5.18(0.12)$ & 18 \\
\hline \multirow[t]{2}{*}{ MBC (mg kg ${ }^{-1}$ soil) } & 2005 & $50.48(3.45)$ & $53.63(4.23)$ & 6 \\
\hline & 2007 & 33.39 (1.89) & $54.42(2.86)$ & 38 \\
\hline \multirow[t]{2}{*}{ MBN (mg kg ${ }^{-1}$ soil) } & 2005 & $6.46(0.77)$ & $6.13(0.57)$ & - \\
\hline & 2007 & $6.07(0.44)$ & $6.58(0.49)$ & 8 \\
\hline \multirow[t]{2}{*}{$\beta$-Glucosidase activity (mg PN kg ${ }^{-1}$ soil $\mathrm{h}^{-1}$ ) } & 2005 & $47.91(1.11)$ & 41.47 (1.97) & - \\
\hline & 2007 & $38.11(2.43)$ & $55.65(4.05)$ & 32 \\
\hline \multirow[t]{2}{*}{$\beta$-Glucosaminidase activity ( $\mathrm{mg} \mathrm{PN} \mathrm{kg}^{-1}$ soil h$^{-1}$ ) } & 2005 & $4.40(0.40)$ & $6.35(0.78)$ & 31 \\
\hline & 2007 & $4.09(0.50)$ & $7.39(0.25)$ & 45 \\
\hline \multirow[t]{2}{*}{$\alpha$-Galactosidase activity (mg PN kg${ }^{-1}$ soil $\mathrm{h}^{-1}$ ) } & 2005 & $1.83(0.18)$ & $1.54(0.35)$ & - \\
\hline & 2007 & $1.40(0.26)$ & $3.82(0.41)$ & 63 \\
\hline \multirow[t]{2}{*}{ Alkaline phosphomonoesterase activity (mg PN kg ${ }^{-1}$ soil $\mathrm{h}^{-1}$ ) } & 2005 & $58.40(2.38)$ & $57.89(2.51)$ & - \\
\hline & 2007 & $41.13(2.52)$ & $71.37(2.14)$ & 42 \\
\hline \multirow[t]{2}{*}{ Phosphodiesterase activity (mg PN kg ${ }^{-1}$ soil h$^{-1}$ ) } & 2005 & $23.66(0.85)$ & $22.55(1.13)$ & - \\
\hline & 2007 & $19.16(2.69)$ & $34.14(2.05)$ & 44 \\
\hline \multirow[t]{2}{*}{ Arylsulfatase activity (mg PN kg ${ }^{-1}$ soil $\mathrm{h}^{-1}$ ) } & 2005 & $1.74(0.13)$ & $2.25(0.38)$ & 23 \\
\hline & 2007 & $1.17(0.34)$ & $2.27(0.32)$ & 48 \\
\hline
\end{tabular}

The $\mathrm{Ct}-\mathrm{Ct}$ (ct) is located in a nearby research site, which has shown generally consistent values for these properties over years. In Nov 2008, MBC (44.83 mg N kg${ }^{-1}$ soil) or MBN (5.76 mg N kg ${ }^{-1}$ soil) and the activities (mg PN kg ${ }^{-1}$ soil h$^{-1}$ ) of $\beta$-glucosaminidase (3.63), $\beta$-glucosidase (38.97), $\alpha$-galactosidase (1.61), alkaline phosphomonoesterase (48.03) phosphodiesterase (21.37), and arylsulfatase (1.61) were close to values reported here for Nov 2005 and 2007. Values in parenthesis represent the standard error from the mean for $\mathrm{Sr}_{\mathrm{g}}-\mathrm{Ct}(n=6)$ and $\mathrm{Ct}-\mathrm{Ct}(n=3)$

high ambient temperatures and low precipitation, interrupted by periods of sudden rain events and wind-induced soil erosion during winter fallow periods (Acosta-Martínez et al. 2007). In fact, the environmental conditions during this 5-year study resulted in different crop biomass production each year, which could be responsible in part for preventing the increase in soil microbial biomass by the crop rotation history of cotton and sorghum earlier (Smith and Paul 1990; Stromberger et al. 2007). Our sampling times every November, however, occurred at post-harvest when weather and soil conditions are most stable for comparisons of the soil microbiological characteristics as recommended by Liebig et al. (2006).

\section{Enzyme activities}

Tillage treatments did not affect the three related EAs of C cycling or the EAs related to $\mathrm{P}$ and $\mathrm{S}$ cycling (alkaline phosphomonoesterase and phosphodiesterase and arylsulfatase) according to 3D plots (Fig. 4). The lack of significant tillage effects on the soil MB and EAs after 5 years is a surprising result as other studies have reported shifts in microbial communities due to tillage (Wortmann et al. 2008). For example, higher fungal populations (i.e., phospholipid fatty acids indicators) under no-till soils compared to tilled counterparts can lead to increases in
EAs (Roldan et al. 2005; Kennedy and Schillinger 2006). Our results may be attributed to the high annual variability of plant biomass production during the study with years of very low residue accumulation in the soil surface under the no-till treatment plots, which may have not exceeded the tilled plots.

Cropping systems with winter cover crops $\left(\mathrm{Sr}_{\mathrm{f}}-\mathrm{Rye}\right.$ and $\mathrm{Ct}-\mathrm{Rye}-\mathrm{Sr}_{\mathrm{g}}$ ) showed a clear separation from those without a winter cover crops history $\left(\mathrm{Sr}_{\mathrm{g}}-\mathrm{Ct}\right.$ and $\left.\mathrm{Ct}-\mathrm{Ct}\right)$ in $3 \mathrm{D}$ plots for samples taken after 3 years (July and Nov 2005) due to higher EAs of $\mathrm{C}$ cycling (Fig. $4 \mathrm{a}, \mathrm{b}$ ) or $\mathrm{P}$ and $\mathrm{S}$ cycling (Fig. 4d, e). A significant separation among cropping systems was detected, but there were no significant differences in soil EAs under $\mathrm{Ct}-\mathrm{Rye}-\mathrm{Sr}_{\mathrm{g}}$ vs. $\mathrm{Sr}_{\mathrm{f}}-\mathrm{Rye}$ or $\mathrm{Sr}_{\mathrm{g}}-\mathrm{Ct}$ vs. $\mathrm{Ct}-\mathrm{Ct}$. The early trends from this study in a sandy soil at the THP agree with studies reporting that MB and arylsulfatase and $\beta$-glucosidase activities were sensitive to alternative management practices, including a winter cover crop after only 1-2 years at 0-7.5 cm (Ndiaye et al. 2000; Schutter et al. 2001). The use of a rye winter cover crop must have incorporated higher biomass in soil and/or the additional rhizosphere effect must have increased microbial biomass and the production of enzymes during winter when compared to cropping systems without winter cover crops $\left(\mathrm{Sr}_{\mathrm{g}}-\mathrm{Ct}\right.$ and $\left.\mathrm{Ct}-\mathrm{Ct}\right)$. The yield produced and/or the soil surface coverage by rye during winters was not significant 

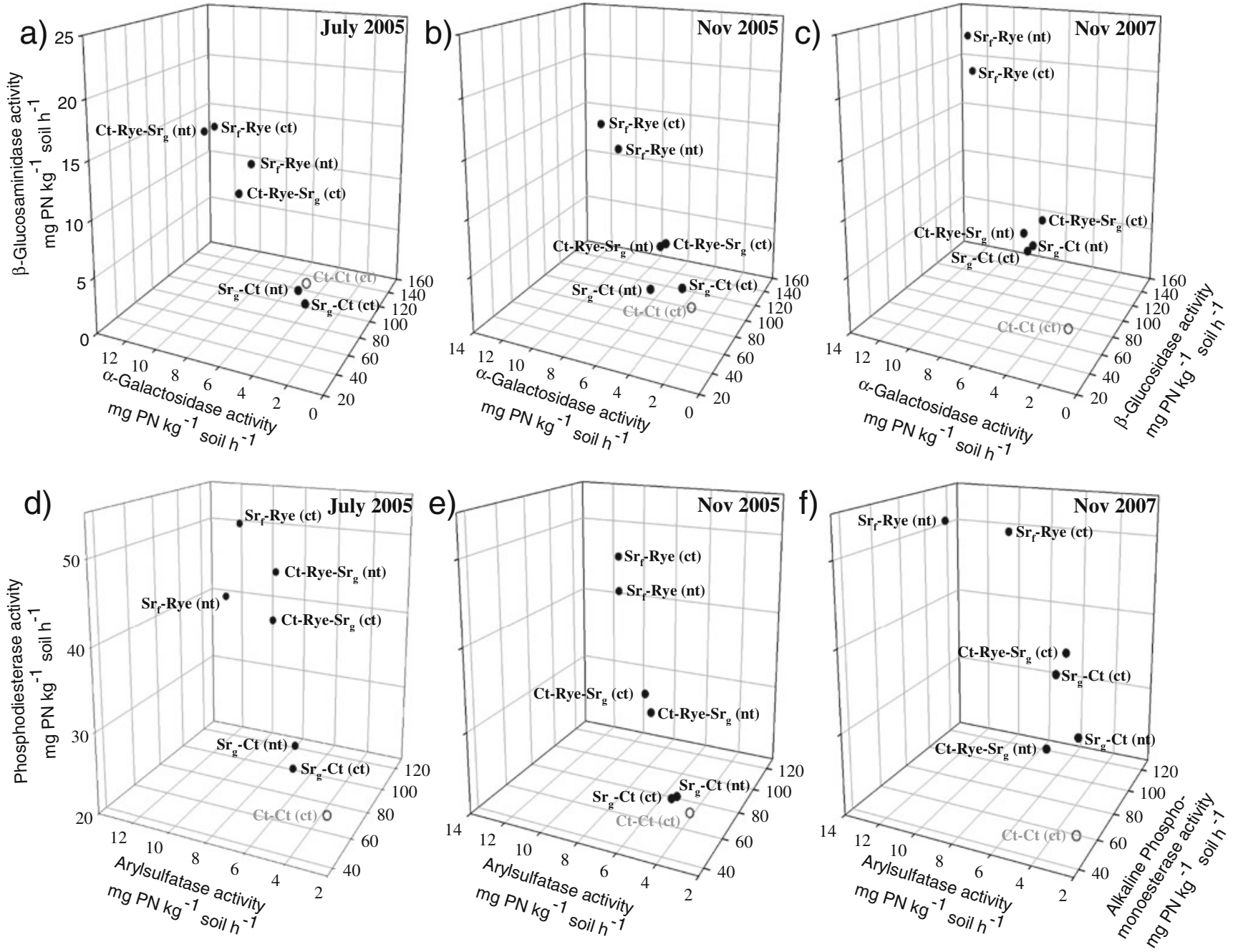

Fig. 4 a-f Three-dimensional plots to investigate the separation among dryland cropping systems according to EAs of $\mathrm{C}$ cycling ( $\beta$-glucosidase, $\beta$-glucosaminidase, and $\alpha$-galactosidase) and $\mathrm{P}$ or $\mathrm{S}$ cycling (alkaline phosphomonoesterase, phosphodiesterase, and arylsulfatase) in July 2005, Nov 2005, and Nov 2007. Continuous cotton $(C t-C t)$ under

compared to forage or grain sorghum, ranging from 42.6 to $304 \mathrm{~kg} \mathrm{ha}^{-1}$ during the study; however, soil under the rotations with winter rye showed definite improvements on MBN and EAs after 3 years.

There was a decrease in soil EAs under $\mathrm{Ct}-\mathrm{Rye}-\mathrm{Sr}_{\mathrm{g}}$ from July to Nov 2005, which ranged from $24 \%$ to $61 \%$ depending on the enzyme (Fig. 4a-d). This was not observed in the other cropping systems, and thus it could reflect a change in microbial community composition and the production of enzymes or in the levels of extracellular enzymes due to changes in substrates availability under $\mathrm{Ct}-\mathrm{Rye}-\mathrm{Sr}_{\mathrm{g}}$, which was the only rotation sampled after cotton in 2005 .

The 3D plots for samples taken after 5 years (Nov 2007) showed that soil under $\mathrm{Sr}_{\mathrm{g}}-\mathrm{Ct}$ reached similar EAs compared to $\mathrm{Ct}-\mathrm{Rye}-\mathrm{Sr}_{\mathrm{g}}$ (Fig. 4c, f) and these properties were higher by $32 \%$ to $63 \%$ depending on the measured conventional tillage $(c t)$ from a nearby research site under the same soil was included in the comparison. The separation between $\mathrm{Sr}_{\mathrm{g}}-\mathrm{Ct}$ and $\mathrm{Sr}_{\mathrm{f}}$-Rye was due to the significant differences in these EAs $(P<0.0001)$ for all sampling times, but the separation between $\mathrm{Sr}_{\mathrm{g}}-\mathrm{Ct}$ and $\mathrm{Ct}-\mathrm{Rye}-$ $\mathrm{Sr}_{\mathrm{g}}$ was not significant for Nov 2007 (c, f)

enzyme activity compared to $\mathrm{Ct}-\mathrm{Ct}$ (Table 3). This was despite the lack of summer crops in 2003 and 2006 and changes in plant biomass during the study. These findings can indicate that rotations of cotton with high-residueproducing crops (i.e., sorghum, corn), even without using winter cover crops, could also be beneficial for improving soil quality and functioning (i.e., nutrient cycling, $\mathrm{C}$ sequestration) beyond 5 years (Causarano et al. 2006; Wright et al 2008).

The changes in EAs as affected by the cropping systems may reflect changes in soil metabolic functioning and nutrient cycling that are explained by shifts in the composition of soil microbial communities (Kandeler et al. 1996; Emmerling et al. 2002). For example, other studies in these cropping systems showed a higher fungal/ bacterial ratio and higher bacterial population densities of 
Bacteroidetes and Proteobacteria under $\mathrm{Sr}_{\mathrm{f}}-\mathrm{Rye}$ compared to cotton-based cropping systems $\left(\mathrm{Sr}_{\mathrm{g}}-\mathrm{Ct}\right.$ and $\left.\mathrm{Ct}-\mathrm{Rye}-\mathrm{Sr}_{\mathrm{g}}\right)$, which may explain the higher EAs under $\mathrm{Sr}_{\mathrm{f}}-\mathrm{Rye}$ (AcostaMartínez et al. 2010b). Shifts in the composition of soil microbial communities increases the enzyme production that may cause an increase in the accumulated enzyme that persists in soil stabilized into clay-soil OM complexes over time (Nannipieri et al. 2002). This enzyme pool may maintain the differences in EAs among cropping systems $\left(\mathrm{Sr}_{\mathrm{f}}-\mathrm{Rye}>\mathrm{Sr}_{\mathrm{g}}-\mathrm{Ct}\right.$ and $\left.\mathrm{Ct}-\mathrm{Rye}-\mathrm{Sr}_{\mathrm{g}}>\mathrm{Ct}-\mathrm{Ct}\right)$ regardless of years when the cropping sequence was affected, if the growing season was not possible, due to insufficient precipitation (Knight and Dick 2004).

Although it is important to evaluate several EAs as a group to have better insights to the soil metabolic capacity as affected by cropping systems, as to what data evaluation tools are chosen in order to understand actual trends is crucial. For example, we also used PCA plots to evaluate all EAs (six) as a group (Fig. 5), but they showed separation among these dryland cropping systems similar to the 3D plots for three related EAs at a time (Fig. 4). The PCA plots did not provide additional information compared to the $3 \mathrm{D}$ plots, and they cannot reveal the actual EAs
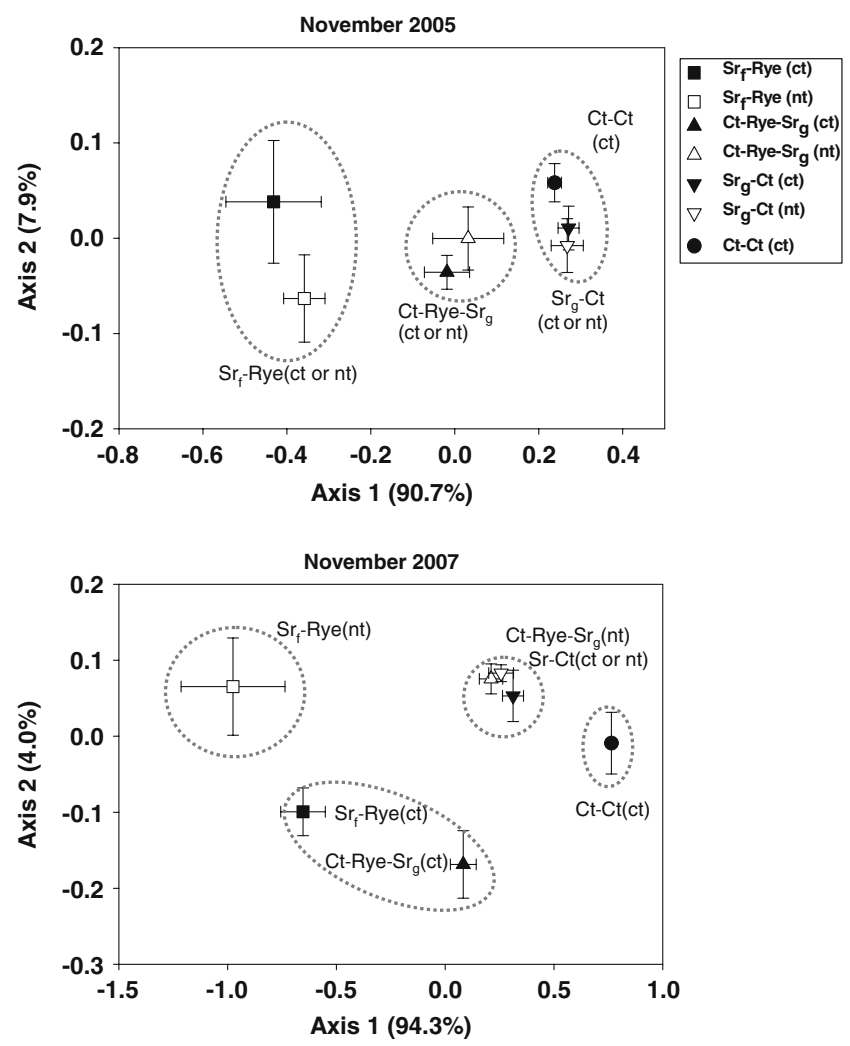

Fig. 5 Principal component analysis of all EAs $(\beta$-glucosidase, $\beta$ glucosaminidase, $\alpha$-galactosidase, alkaline phosphomonoesterase, phosphodiesterase, and arylsulfatase) together after 3 years (Nov 2005) and 5 years (Nov 2007). The data shown are the means \pm SEM for each cropping system and tillage combination shown by the $3 \mathrm{D}$ plots. In addition, the PCA plot for the Nov 2007 sampling (year 5) showed a separation of tillage treatments for some cropping systems that should be taken with caution because there were no significant tillage effects in this study. For example, the separation due to tillage for $\mathrm{Sr}_{\mathrm{f}}-$ Rye was due to the higher activities of alkaline phosphomonoesterase (13\%) and phosphodiesterase $(17 \%)$ under nt compared to ct, but the same separation for $\mathrm{Ct}-\mathrm{Rye}-\mathrm{Sr}_{\mathrm{g}}$ was due to the higher activities of $\beta$ glucosidase (29\%) and phosphodiesterase (7\%) under ct than nt (Fig. 4c, f).

Correlation between soil and/or plant properties

The MB showed a positive and significant correlation with EAs $(r>0.42, P<0.05, n=42)$ reinforcing our belief that increases in $\mathrm{MB}$ were followed by increases in enzyme synthesis in cropping systems with winter cover crops and less frequency of cotton (data not shown). Soil MB and EAs were positively correlated to total $\mathrm{C}$ or total $\mathrm{N}(r>0.48, P<$ $0.05, n=42$ ) in this sandy soil. Higher soil TC content was detected under $\mathrm{Sr}_{\mathrm{f}}-\mathrm{Rye}$ compared to $\mathrm{Sr}_{\mathrm{g}}-\mathrm{Ct}$ despite tillage after 5 years (Nov 2007), and it was similar in soil under CtRye- $-\mathrm{Sr}_{\mathrm{g}}$ and $\mathrm{Sr}_{\mathrm{g}}-\mathrm{Ct}$, but these results were anticipated by $\mathrm{MB}$ after 3 years only. However, it is important to recognize that there may be also changes in soil OM quality influenced by these cropping systems that are not detected with total $\mathrm{C}$ determinations. The detection after 5 years of differences in soil OM content under $\mathrm{Sr}_{\mathrm{f}}$-Rye compared to the other systems is surprising because it has been postulated that changes in soil OM occurs over longer time periods for soils with high OM (Powlson et al. 1987).

Positive significant correlations were also found between plant biomass with soil MBC $(r=0.72, P<0.01, n=42), \mathrm{MBN}$ $(r=0.62, P<0.01, n=42)$, and EAs $(r>0.62, P<0.01, n=42)$. In addition, the 2007 soil sampling revealed a positive correlation between $\mathrm{MBC}, \mathrm{MBN}$, and EAs data with cotton lint yields determined in 2008 when all these systems were placed under cotton $(r>0.43, P<0.01, n=42)$. This is an important finding as cotton yields were not significantly affected by these cropping systems during the 5 years of this study. These data for this sandy soil under dryland production indicated the potential of these soil microbial properties as early indicators of crop yields. These findings prove that soil microbial communities are important factors in soil fertility and crop productivity.

\section{Conclusions}

This study demonstrated that differences in MB or EAs are more affected by crop rotation than tillage management for this sandy soil under dryland production in a semiarid 
region. After only 3 years, rotations including winter cover crops in years, when precipitation and air temperature permitted the winter crop (e.g., $\mathrm{Sr}_{\mathrm{f}}-\mathrm{Rye}$ and $\mathrm{Ct}-\mathrm{Rye}-\mathrm{Sr}_{\mathrm{g}}$ ), must have provided higher nutrients in soil through plant biomass return, which explains these fast increases in soil MBN and EAs compared to $\mathrm{Sr}_{\mathrm{g}}-\mathrm{Ct}$ or $\mathrm{Ct}-\mathrm{Ct}$. After 5 years, soil under $\mathrm{Sr}_{\mathrm{g}}-\mathrm{Ct}$ reached similar $\mathrm{MB}$ and EAs compared to $\mathrm{Ct}-\mathrm{Rye}-\mathrm{Sr}_{\mathrm{g}}$, and these properties were higher compared to $\mathrm{Ct}-\mathrm{Ct}$. These findings with MB and EAs are regarded as positive impacts on key soil quality parameters related to soil $\mathrm{OM}$, nutrient cycling, and $\mathrm{C}$ sequestration with alternative cropping systems that include a history of winter cover crop and/or rotations of cotton with high biomass crops such as sorghum for this region.

Acknowledgements The initiation of this study in 2003 was possible due to the funding from the Ogallala Aquifer Research Initiative in that year. This research was also supported by the Agricultural Research Service under the GRACEnet Project.

\section{References}

Acosta-Martínez V, Bell CE, Morris BEL, Zak J, Allen VG (2010a) Long-term soil microbial community and enzyme activity responses to an integrated cropping-livestock system in a semiarid region. Agric Ecosyst Environ 137:231-240

Acosta-Martínez V, Dowd SE, Bell CW, Lascano R, Booker JD, Zobeck TM, Upchurch DR (2010b) Microbial community composition as affected by Dryland cropping systems and tillage in a semiarid sandy soil. Diversity 2:910-931

Acosta-Martínez V, Mikha M, Vigil MF (2007) Microbial communities and enzyme activities in soils under alternative crop rotations compared to wheat-fallow for the Central Great Plains. Appl Soil Ecol 37:41-52

Acosta-Martínez V, Rowland D, Sorensen RB, Yeater KM (2008) Microbial community structure and functionality under peanutbased cropping systems in a sandy soil. Biol Fertil Soils 44:681-692

Acosta-Martínez V, Zobeck TM, Allen VG (2004) Soil microbial, chemical and physical properties in continuous cotton and integrated crop-livestock systems. Soil Sci Soc Am J 68:1875-1884

Allen VG, Brown CP, Kellison R, Segarra E, Green CJ, Wheeler TA, Dotray PA, Conkwright JC, Green CJ, Acosta-Martinez V (2005) Integrating cotton and beef production to reduce water withdrawal from the Ogallala Aquifer in the Southern High Plains. Agron J 97:556-567

Allen VG, Brown CP, Segarra E, Green CJ, Wheeler TA, AcostaMartinez V, Zobeck TM (2008) In search of sustainable agricultural systems for the Llano Estacado of the U.S. Southern High Plains. Agric Ecosyst Environ 124:3-12

Brookes PC, Landman A, Pruden G, Jenkinson DS (1985) Chloroform fumigation and the release of soil nitrogen: a rapid direct extraction method to measure microbial biomass nitrogen in soil. Soil Biol Biochem 17:837-842

Bronson KF, Onken AB, Booker JD, Lascano RJ, Provin TL, Torbert HA (2001) Irrigated cotton yields as affected by phosphorus fertilizer and landscape position. Commun Soil Sci Plant Anal 32:1959-1967

Causarano HJ, Franzluebbers AJ, Reeves DW, Shaw JN (2006) Soil organic carbon sequestration in cotton production systems of the southeastern United States: a review. J Environ Qual 35:1374-1383
Doran JW, Parkin TB (1994) Defining and assessing soil quality. In: Doran JW, Coleman DC, Bezdicek DF, Stewart BA (eds) Defining soil quality for a sustainable environment. SSSA Spec Publ No. 35, Soil Sci Soc Am and Am Soc Agron, Madison, WI, pp 3-21

Emmerling C, Schloter M, Hartmann A, Kandeler E (2002) Functional diversity of soil organisms - a review of recent research activities in Germany. J Plant Nutr Soil Sci 165:408-420

Feng Y, Mottaa AC, Reeves DW, Burmestera CH, van Santena E, Osbornec JA (2003) Soil microbial communities under conventional-till and no-till continuous cotton systems. Soil Biol Biochem 35:1693-1703

Franzluebbers AJ (2002) Soil organic matter stratification ratio as an indicator of soil quality. Soil Tillage Res 66:95-106

Franzluebbers AJ, Hons FM, Zuberer AD (1994) Long-term changes in soil carbon and nitrogen pools in wheat management systems. Soil Sci Soc Am J 58:1639-1645

Jenkinson DS (1988) Determination of microbial biomass carbon and nitrogen in soil. In: JR Wilson (ed) Advances in nitrogen cycling in agricultural ecosystems. CAB Int., Walling-ford, pp 368-386

Kandeler E, Kampichler C, Horak O (1996) Influence of heavy metals on the functional diversity of soil microbial communities. Biol Fertil Soils 23:299-306

Karlen DL, Rosek MJ, Gardner JC, Allan DL, Alms MJ, Bezdicek DF, Flock M, Huggins DR, Miller BS, Staben ML (1999) Conservation reserve program effects on soil quality indicators. J Soil Water Conserv 54:439-444

Keeney DR, Nelson DW (1982) 33-3 Extraction of exchangeable ammonium, nitrate, and nitrite. In: Page AL, Miller RH, Keeney DR (eds) Methods of soil analysis. Part 2. Chemical and microbiological properties. Agronomy Monograph No. 9, 2nd edn. ASA-SSSA, Madison, pp 648-649

Kennedy AC, Schillinger WF (2006) Soil quality and water intake in traditional-till vs. no-till paired farms in Washington's Palouse region. Soil Sci Soc Am J 70:940-949

Knight TR, Dick RP (2004) Differentiating microbial and stabilized $\beta$-glucosidase activity relative to soil quality. Soil Biol Biochem 36:2089-2096

Lal R (2004) Carbon sequestration in soils of central Asia. Land Degrad Dev 15:563-572

Lascano RJ (2000) A general system to measure and to calculate daily crop water use. Agron J 82:821-832

Liebig M, Carpenter-Boggs L, Johnson JMF, Wright S, Barbour N (2006) Cropping system effects on the soil biological characteristics in the Great Plains. Renew Agric Food Syst 21:36-48

Lynch JM, Bragg E (1985) Microorganisms and soil aggregate stability. In: Advances in soil science, vol 2. Springer, New York, pp 133-171

McCune B, Mefford MJ (1999) Multivariate analysis on the PC-ORD system. Version 4. MjM Software, Gleneden Beach

Mehlich A (1984) Mehlich-3 soil test extractant: a modification of mehlich-2 extractant. Commun Soil Sci Plant Anal 15:14091416

Moore JM, Klose S, Tabatabai MA (2000) Soil microbial biomass carbon and nitrogen as affected by cropping systems. Biol Fertil Soils 31:200-210

Nannipieri P, Kandeler E, Ruggiero P (2002) Enzyme activities and microbiological and biochemical processes in soil. In: Burns RG, Dick RP (eds) Enzymes in the environment. Activity, ecology and applications. Marcel Dekker, New York, pp 1-33

Ndiaye EL, Sandeno D, McGrath D, Dick RP (2000) Integrative biological indicators for detecting changes in soil quality. Am J Altern Agric 15:26-36

Parham JA, Deng SP (2000) Detection, quantification and characterization of $\beta$-glucosaminidase activity in soil. Soil Biol Biochem $32: 1183-1190$ 
Powlson DS, Prookes PC, Christensen BT (1987) Measurement of soil microbial biomass provides an early indication of changes in total soil organic matter due to straw incorporation. Soil Biol Biochem 19:159-164

Roldan A, Salinas-Garcia JR, Alguacil MM, Diaz E, Caravaca F (2005) Soil enzyme activities suggest advantages of conservation tillage practices in sorghum cultivation under subtropical conditions. Geoderma 129-178:185

Ryan M (1999) In an enhanced soil biological community, relative to conventional neighbours, a consistent feature of alternative (organic and biodynamic) agricultural systems? Biol Agric Hortic 17:131-144

Sainju UM, Singh BP, Whitehead WF (2005) Tillage, cover crops, and nitrogen fertilization effects on cotton and sorghum root biomass, carbon, and nitrogen. Agron J 97:1279-1290

Schutter ME, Sandeno JM, Dick RP (2001) Seasonal, soil type, alternative management influences on microbial communities of vegetable cropping systems. Biol Fertil Soils 34:397-410

Smith JL, Paul EA (1990) The significance of soil microbial biomass estimations. In: Bollag JM, Strotzky G (eds) Soil biochemistry, vol 6. Marcel Dekker, New York, pp 357-396

Sotomayor-Ramírez D, Espinoza Y, Acosta-Martínez V (2009) Land use effects on microbial biomass $C, \beta$-glucosidase and $\beta$ glucosaminidase activities, and availability, storage, and age of organic C in soil. Biol Fertil Soils 45:487-497
Stromberger M, Shah Z, Westfall D (2007) Soil microbial communities of no-till dryland ecosystems across an evaporation gradient. Appl Soil Ecol 35:94-106

Tabatabai MA (1994) Soil enzymes. In: Weaver RW, Angle JS, Bottomley PS (eds) Methods of soil analysis. Part 2. Microbiological and biochemical properties, vol 5, SSSA Book. Soil Science Society of America, Madison, pp 775-833

Tabatabai MA, Ekenler M, Senwo ZN (2010) Significance of enzyme activities in soil nitrogen mineralization. Commun Soil Sci Plant Anal 41:595-605

Unger PW, Parker JJ (1976) Evaporation reduction from soil with wheat, sorghum, and cotton residues. Soil Sci Soc Am J 40:938-942

Vance ED, Brookes PC, Jenkinson DS (1987) An extraction method for measuring microbial biomass C. Soil Biol Biochem 19:703-707

Wortmann CS, Quincke JA, Drijber RA, Mamo M, Franti T (2008) Soil microbial community change and recovery after one-time tillage of continuous no-till. Agron J 100:1681-1686

Wright AL, Hons FM, Lemon RG, McFarland ML, Nichols RL (2008) Microbial activity and soil C sequestration for reduced and conventional tillage cotton. Appl Soil Ecol 38:168-173

Wu J, Joergensen RG, Pommerening B, Chaussod R, Brookes PC (1990) Measurement of soil microbial biomass C by fumigation extraction-an autoclaved procedure. Soil Biol Biochem 22:1167-1169 